\title{
Soil organic matter in crop rotations under no-till
}

\author{
Juan P.A. Raphael ${ }^{\mathrm{a}}$, Juliano C. Calonego ${ }^{\mathrm{a}}$, Debora Marcondes B.P. Milori ${ }^{\mathrm{b}}$, \\ Ciro A. Rosolem ${ }^{\mathrm{a}, *}$ \\ ${ }^{a}$ Department of Crop Science, College of Agricultural Sciences, São Paulo State Univerisity, José Barbosa de Barros Street 1780, 18610-307 Botucatu, São Paulo, \\ Brazil \\ b Embrapa Instrumentation, São Paulo, Brazil
}

\section{A R T I C L E I N F O}

\section{Article history:}

Received 11 June 2015

Received in revised form 16 July 2015

Accepted 19 July 2015

\section{Keywords:}

Soil management

Cover crops

\begin{abstract}
A B S T R A C T
Soil organic matter conservation, paramount in tropical agriculture, is affected by the composition of cultivated plant species and the input of dry matter and nitrogen into the system. However, SOM development in tropical soils managed under no-till in the long term is not well understood. The objective of this study was to evaluate SOM concentration and quality as a result of crop rotations under NT in two soils in Botucatu, Brazil, over a 10-year experimental period (2003-2012). Crop rotations including grasses and a legume grown in the fall/winter and spring were conducted for seven years in a clay Rhodic Hapludox. In a clay Typic Rhodudalf, crop rotations were compared with a fallow/chiseled treatment for 10 years. The cash crop was soybean grown every year in the summer. In both experiments, SOM lability was affected mainly by the spring crops. The absence of spring cover crops in chiseled treatments resulted in less total organic carbon in the $0.0-0.10 \mathrm{~m}$ soil depth. Soil concentration of TOC and its fractions were higher under crop rotations with higher nitrogen input, especially where sunn hemp was grown in spring. The strongest effects occurred in the Typic Rhodudalf, probably as a result of its higher clay content and the longer period under crop rotation. Under NT, the increase in labile and stable SOM is limited by the lack of cover crops in the spring or $\mathrm{N}$ availability. However, SOM humification degree is decreased with higher $C$ input. These results highlight the importance of the use of cover crops and nitrogen inputs in soil conservation strategies and the sustainability of agricultural systems in the tropics.
\end{abstract}

(c) 2015 Elsevier B.V. All rights reserved.

\section{Introduction}

Soil organic matter is an indicator of soil quality (Larson and Pierce, 1994; Kang et al., 2005) with important agronomic and environmental functions (Schmidt et al., 2011). SOM contributes to increase soil fertility (Kaiser et al., 2008), physical (Bronick and Lal, 2005), hydric (Franzluebbers, 2002; Smagin et al., 2004), and biological (Hargreaves et al., 2003) properties. Therefore, strategies that allow for the accumulation of stable SOM in the soil are essential, especially in the tropics with dry winters where SOM is low due to the rapid decomposition of plant residues and low dry

\footnotetext{
Abreviavions: SOM, ,soil organic Matter; NT, ,no-till; TOC, ,total organic carbon;

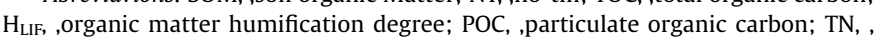
total nitrogen; $\mathrm{MOC}$, mineral associated carbon; $\mathrm{C}_{\mathrm{SMB}}$, microbial biomass carbon; $\mathrm{N}_{\mathrm{SMB}}$, ,microbial biomass nitrogen.

* Corresponding author.

E-mail addresses: juanpiero1@gmail.com (J.P.A. Raphael), juliano@unoeste.br (J.C. Calonego), debora.milori@empraba.br(D.M.B.P. Milori), rosolem@fca.unesp.br (C.A. Rosolem).
}

matter input by cover crops (Bolliger et al., 2006). No-till may increase SOM because of the constant addition of crop residues to the soil surface. Both the decomposition rate (Nunes et al., 2011) and carbon emissions to the atmosphere (Bayer et al., 2009) are low, especially when there is a high and diverse supply of $C$ from the biomass in crop rotation (Tivet et al., 2013; Conceição et al., 2013). Although positive effects of NT on SOM are well known, little is known about the effect of crop rotation within this management system. Each species can affect the concentration and quality of SOM by the differential contribution of phytomass, the intrinsic characteristics of plant residues, the root system, and the influence on the microbial community, which is a fundamental component in SOM accumulation (Tivet et al., 2013).

A positive balance of nitrogen in the tropical and sub-tropical agro-ecosystems through the biological fixation of $\mathrm{N}_{2}$ has been considered as fundamental for $\mathrm{C}$ sequestration (Boddey et al., 2008). The $\mathrm{N}$ that is added to the soil from each plant species in a crop rotation affects the production of phytomass and the microbial metabolism (Balota et al., 2003), and plays an important role in SOM dynamics, since the proportion of organic $\mathrm{N}$ in the total 


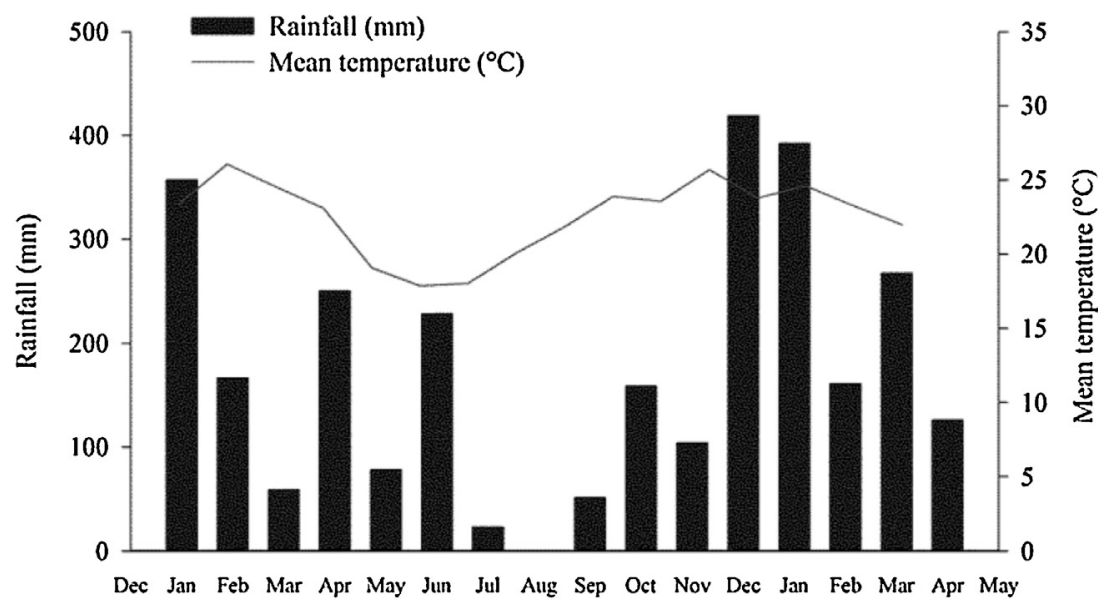

Fig. 1. Rainfall and mean monthly temperatures from January 2012 to April 2013, at the Lageado Experimental Farm (FCA/UNESP). Botucatu, São Paulo, Brazil.

$\mathrm{N}$ is high (Stevenson, 1982). In crop rotations, species that have the potential to add $\mathrm{N}$ to the soil can increase the phytomass production of the following crops, which is as source material for the formation of SOM (Peoples and Baldock, 2001), hence, the $\mathrm{C} / \mathrm{N}$ ratio of the soil is another factor to be considered. The $\mathrm{C} / \mathrm{N}$ ratio of the soil is an indicator of $\mathrm{N}$ retention by microbial communities (Mooshammer et al., 2014). A high $\mathrm{C} / \mathrm{N}$ ratio, due to a relative excess organic $\mathrm{C}$, results in the immobilization of $\mathrm{N}$ in the soil, while a low $\mathrm{C} / \mathrm{N}$ ratio, due to excess $\mathrm{N}$, results in the mineralization of $\mathrm{N}$ in the soil. According to Stevenson (1994), in undisturbed tropical soils, the equilibrium of $\mathrm{C} / \mathrm{N}$ ranges between 10 and 15 . In addition, the composition of plants that produce residues has an important role in the determination of this ratio. The $\mathrm{C} / \mathrm{N}$ and lignin/ $\mathrm{N}$ ratios of each species indicate a higher or lower resistance of the material to decomposition. Higher $\mathrm{C} / \mathrm{N}$ and lignin/ $\mathrm{N}$ are known to increase the resistance of the material to decomposition and $\mathrm{N}$ mineralization (Zech et al., 1997).

Thus, SOM can be affected by the plant species present in a crop rotation and it depends on the input of dry matter and $\mathrm{N}$. In the absence of mineral nitrogen fertilization, SOM may be increased with the use of species that accumulate more $\mathrm{N}$, and this increase may be observed in more and less labile fractions. Thus, the objective of this study was to evaluate the concentration and quality of SOM as a result of crop rotation under NT, with no added mineral nitrogen, in two different soil types (Rhodic Hapludox and Typic Rhodudalf) over an experimental period of 10 years.

\section{Materials and methods}

\subsection{Experimental site and treatments}

Two experiments were conducted in Botucatu, Sao Paulo, Brazil $\left(22^{\circ} 49^{\prime} \mathrm{S}, 48^{\circ} 25^{\prime} \mathrm{W}\right.$, altitude: $\left.786 \mathrm{~m}\right)$, in areas under no-till over 7 and 10-year experimental period. The climate is mesothermal with a well-defined dry season between May and September. The average annual rainfall is $1450 \mathrm{~mm}$. The highest and lowest temperatures and the monthly precipitation averages between December 2011 and April 2013 are shown in Fig. 1. The soils are classified as clay Rhodic Hapludox and clay Typic Rhodudalf (Soil Survey Staff, 2014). Some chemical (Raij et al., 2001) and physical (Embrapa, 1997) characteristics of the soils are in Table 1.

In both soils the experimental design was a split-plot arrangement in complete randomized blocks, with four replications. The plots consisted of fall/winter crop species and the subplots of spring crop species. Soybeans (Glycine max (L.) Merrill) were grown in the full area in the summer. Crop rotation was repeated annually. In both experiments, fertilizers $\left(50 \mathrm{~kg} \mathrm{ha}^{-1}\right.$ of $\mathrm{K}_{2} \mathrm{O}$ and $50 \mathrm{~kg} \mathrm{ha}^{-1}$ of $\mathrm{P}_{2} \mathrm{O}_{5}$, as potassium chloride and triple superphosphate, respectively) were applied to soybean at planting. The fall/winter crops were harvested every year between the second week of August and the first week of September with a plot harvester.

The experiment in the Rhodic Hapludox soil began in 2006 with grain sorghum (Sorghum vulgare), ruzigrass (Urochloa ruziziensis ( $\mathrm{R}$. Germ. \& C. M. Evard) Crins), and a mixture of both species (grain sorghum + ruzigrass) grown in fall/winter (plots), followed by pearl

Table 1

Selected chemical and physical properties of the soils bi the time the experiments were started.

\begin{tabular}{|c|c|c|c|c|c|c|c|c|c|c|c|}
\hline $\begin{array}{l}\text { Soil Depth } \\
(\mathrm{m})\end{array}$ & $\begin{array}{l}\mathrm{pH} \\
\mathrm{CaCl}_{2}\end{array}$ & $\begin{array}{l}P^{\mathrm{a}} \\
\mathrm{mg} \mathrm{dm}\end{array}$ & Al & $\begin{array}{l}\mathrm{H}+\mathrm{Al} \\
{ }_{\mathrm{c}} \mathrm{dm}^{-3}\end{array}$ & $\mathrm{Ca}$ & $\mathrm{Mg}$ & K & $\begin{array}{l}\text { SBS } \\
\%\end{array}$ & Sand & $\begin{array}{c}\text { Clay } \\
--\end{array}$ & Silt \\
\hline \multicolumn{12}{|c|}{ Rhodic Hapludox } \\
\hline $0-0.10$ & 5.2 & 15 & 1 & 27 & 57 & 24 & 1.0 & 75 & 501 & 405 & 95 \\
\hline $0.10-0.20$ & 4.7 & 12 & 2 & 40 & 34 & 16 & 0.7 & 56 & 475 & 455 & 71 \\
\hline $0.20-0.40$ & 4.1 & 7 & 8 & 62 & 20 & 11 & 0.5 & 33 & 413 & 505 & 82 \\
\hline $0.40-0.60$ & 3.8 & 6 & 17 & 99 & 12 & 8 & 0.4 & 17 & 375 & 505 & 120 \\
\hline \multicolumn{12}{|c|}{ Typic Rhodudalf } \\
\hline $0-0.10$ & 4.9 & 33 & 2 & 54 & 71 & 34 & 3.2 & 66 & 108 & 655 & 238 \\
\hline $0.10-0.20$ & 4.4 & 12 & 7 & 75 & 32 & 12 & 1.3 & 37 & 100 & 655 & 245 \\
\hline $0.20-0.40$ & 4.2 & 21 & 9 & 93 & 31 & 14 & 2.2 & 33 & 84 & 705 & 211 \\
\hline $0.40-0.60$ & 4.3 & 11 & 12 & 102 & 35 & 12 & 0.7 & 32 & 66 & 730 & 204 \\
\hline
\end{tabular}

SBS (soil base saturation)

a $P_{\text {resin. }}$ 
millet (Pennisetum glaucum L.), forage sorghum (Sorghum bicolor (L.) Moench) and sunn hemp (Crotalaria juncea L.) in the spring (subplots). Sub-plots were $5.0 \mathrm{~m}$ wide by $10.0 \mathrm{~m}$ long, and the plots were $5.0 \mathrm{~m}$ wide by $36.0 \mathrm{~m}$ long. Plots and blocks were set $3.0 \mathrm{~m}$ apart to allow for machine traffic. Ruzigrass was planted in $0.17 \mathrm{~m}$ spaced rows using $22 \mathrm{~kg} \mathrm{ha}^{-1}$ of seeds, while grain sorghum was planted in $0.34 \mathrm{~m}$ spaced rows using $11 \mathrm{~kg} \mathrm{ha}^{-1}$ of seeds. For the mixture, rows were spaced at $0.34 \mathrm{~m}$ and the same quantities of seed were used as in the single crops. Ruzigrass seeds were placed in the fertilizer bin of the grain seeder and deposited in the same row with grain sorghum. In both experiments, pearl millet, sunn hemp, and forage sorghum were planted in the first half of October at $0.17 \mathrm{~m}$ row spacing and 25,30 , and $15 \mathrm{~kg} \mathrm{ha}^{-1}$ of seeds, respectively. In the first half of December, approximately $60 \mathrm{~d}$ after planting, plots and subplots were chemically desiccated with glyphosate, and then soybean was sown at $0.45 \mathrm{~m}$ spaced rows and a density of 355,000 seeds ha ${ }^{-1}$.

The experiment in the Typic Rhodudalf began in 2003 with triticale ( $\times$ Triticosecale [Wittmack]) and sunflower (Helianthus annuus L.) grown in fall/winter (plots), followed by pearl millet, forage sorghum, and sunn hemp in spring (subplots). A fallow check treatment was included, where chiseling was carried out in 2003 and 2009, before soybean planting. The chisel plow had seven shanks mounted on two parallel bars. The shanks, inclined $25^{\circ}$ forward, were set $0.60 \mathrm{~m}$ apart, resulting in an effective betweenshank spacing of $0.30 \mathrm{~m}$, with a maximum depth of $0.30 \mathrm{~m}$. A clodbreaking roller was attached to break clods, decrease surface roughness and avoid harrowing. Plots under fallow were mowed for weed control 30 days after the other plots had been planted. Triticale was planted in rows $0.17 \mathrm{~m}$ apart from each other, using $165 \mathrm{~kg} \mathrm{ha}^{-1}$ of seeds, while sunflower was grown in rows $0.51 \mathrm{~m}$ apart from each other, using $22 \mathrm{~kg} \mathrm{ha}^{-1}$ of seeds. Plots were $8.0 \times 32.0 \mathrm{~m}$, and sub-plots were $8.0 \times 5.0 \mathrm{~m}$, with $4.0 \mathrm{~m}$ between blocks, plots and sub-plots. The fall/winter crops were harvested every year between the second week of August and the first week of September with a plot harvester.

\subsection{Sample collection and analysis - plant and straw}

Concentrations of $\mathrm{C}$ and $\mathrm{N}$ were determined in the plant species in both experiments in samples collected in 2012. Soybeans and the fall/ winter grain crops were sampled at harvest, while the cover crops were sampled in fall/winter and spring crops at the pre-flowering stage, i.e., before chemical desiccation. Samples comprised two subsamples per subplot, collected with a $0.5 \mathrm{~m} \times 0.5 \mathrm{~m}$ frame. The samples were dried in a forced-air oven at $65^{\circ} \mathrm{C}$, ground and analyzed for $\mathrm{C}$ and $\mathrm{N}$ concentrations using an elemental analyzer (LECOTruSpec $($ CHNS). Samples from each plant species were mixed and homogenized, and two samples were taken and analyzed for cellulose, hemicellulose, and lignin (Silva and Queiroz, 2002). These analyzes were not performed for the mixture of sorghum/ruzigrass. The results are presented in Table 2.

Table 2

Selected $\mathbf{c}$ hemical characteristics of the species used in the crop rotation systems.

\begin{tabular}{|c|c|c|c|c|c|c|c|}
\hline Crop & Hemicellulose & Cellulose & Lignin & C & $\mathrm{N}$ & $\begin{array}{l}\mathrm{Cl} \\
\mathrm{N}\end{array}$ & $\begin{array}{l}\text { Lignin/ } \\
\mathrm{N}\end{array}$ \\
\hline Sunn hemp & 11.9 & 33.8 & 14.9 & 44.7 & 2.86 & 16 & 5 \\
\hline Soybean straw & 12.0 & 44.6 & 30.4 & 45.3 & 0.75 & 61 & 41 \\
\hline Ruzigrass & 27.5 & 24.0 & 10.1 & 44.5 & 2.44 & 18 & 4 \\
\hline Pearl millet & 32.5 & 28.4 & 4.7 & 43.8 & 1.30 & 34 & 4 \\
\hline $\begin{array}{l}\text { Forage } \\
\text { sorghum }\end{array}$ & 34.7 & 35.4 & 5.4 & 46.3 & 0.87 & 53 & 6 \\
\hline Grain Sorgum & 35.9 & 34.7 & 7.1 & 45.4 & 0.74 & 61 & 10 \\
\hline Triticale & 20.0 & 49.2 & 17.3 & 45.1 & 0.47 & 96 & 37 \\
\hline Sunflower & 9.9 & 48.0 & 21.1 & 44.2 & 0.67 & 66 & 32 \\
\hline
\end{tabular}

To evaluate the annual accumulation of dry matter, $\mathrm{C}$, and $\mathrm{N}$ of plant residues in each crop rotation, the remaining straw in the soil was sampled after soybean harvest on April 20, 2012, after the fall/ winter crops on October 4, 2012, and after the spring crops on December 4, 2012. The samples were dried in a forced-air oven at $65^{\circ} \mathrm{C}$ and weighed. Thereafter, the annual input of dry matter, $\mathrm{C}$, and $\mathrm{N}$ of straw from each crop rotation was calculated. The collection and analysis methods of $\mathrm{C}$ and $\mathrm{N}$ in the straw were the same as those described for the analysis of $\mathrm{C}$ and $\mathrm{N}$ in the plant material, with the exception that in the former only one sample per experimental unit was taken.

\subsection{Soil sample collection and analysis}

Soil samples were collected at 0-0.10, 0.10-0.20, 0.20-0.40, and $0.40-0.60 \mathrm{~m}$ depths with a soil core probe after soybean harvest in April 2012 to analyze organic matter humification degree and in April 2013 to analyze total organic carbon, total nitrogen, and physical fractionation of SOM. In order to determine soil TOC and TN, samples were air-dried, sieved through a 2-mm mesh, and analyzed with an elemental analyzer (LECO-TruSpec $®$ CHNS), using $0.2 \mathrm{~g}$ of soil. For the SOM physical fractionation, a granulometric method was used as described by Cambardella and Elliot (1992). Air-dried soil samples of $20 \mathrm{~g}$ were sieved through $2-\mathrm{mm}$ mesh and weighed in $250-\mathrm{mL}$ polyethylene cups, in which $80 \mathrm{~mL}$ of $5 \mathrm{~g} \mathrm{~L}^{-1}$ sodium hexametaphosphate was added. The samples were stirred for $15 \mathrm{~h}$ on a horizontal stirrer, sieved through $0.053-\mathrm{mm}$ mesh, and rinsed until the clay was completely removed. The particulate material remaining on the sieve was transferred to aluminum pots and dried to constant mass in a forced-air oven at $50^{\circ} \mathrm{C}$. After drying, the material was weighed, ground in a porcelain mortar, homogenized with the aid of a glass rod, and $C$ was determined using an elemental analyzer. Then, the soil particulate organic carbon was calculated. The soil MOC was obtained by the difference between TOC and POC. The degree of humification was determined by laser-induced fluorescence $\left(\mathrm{H}_{\mathrm{LIF}}\right)$ (Milori et al., 2006; Santos et al., 2015). Samples were dried, homogenized, ground in a porcelain mortar, and sieved through $0.149-\mathrm{mm}$ mesh. A subsample was used to determine TOC by elemental analysis and another was used to determine $\mathrm{H}_{\text {LIF. }}$ A 0.5 -g soil sample was subjected to compression under hydraulic press to produce circular flat-faced tablets, which were subjected to laser-induced fluorescence analysis as described by Milori et al. (2006). This apparatus produces a fluorescence emission spectrum, represented by an emission curve. The fluorescence emission is caused by the humified organic matter. $\mathrm{H}_{\text {LIF }}$ is calculated as the ratio of the area under the fluorescence emission curve to TOC. The soil $\mathrm{C}_{\mathrm{SMB}}$ (Islam and Weil, 1998) and $\mathrm{N}_{\mathrm{SMB}}$ (Mendonça and Matos, 2005) were determined only in soil samples taken at the $0-0.10 \mathrm{~m}$ soil depth in April 2013. For these analyzes, soil samples were sieved through a $2 \mathrm{~mm}$ sieve and 20 -g oven-dried equivalent of soil were placed in $150 \mathrm{~mL}$-microwave-resistant polypropylene bottles. For each soil sample, two subsamples were taken, half for direct extraction and half for irradiation with a $623 \mathrm{~W}$ household-type microwave oven. After irradiation, $80 \mathrm{~mL}$ of $0.5 \mathrm{M}$ $\mathrm{K}_{2} \mathrm{SO}_{4}$ were added and the samples were transferred to a horizontal shaker $(220 \mathrm{rpm})$ for $30 \mathrm{~min}$. The extracts were filtered through quantitative filter paper for $\mathrm{C}$ and $\mathrm{N}$ determination. Soil biomass $\mathrm{C}$ and $\mathrm{N}$ were calculated from the difference between irradiated and nonirradiated extracts, and the $\mathrm{C}_{\mathrm{SMB}} / \mathrm{TOC}$ and $\mathrm{N}_{\mathrm{SMB}} / \mathrm{TN}$ ratios were calculated.

\subsection{Statistical analysis}

Results were subjected to ANOVA and the averages were compared by the $t$-test (LSD, $\mathrm{P}<0.05$ ), using SAS version 9.2 (SAS Institute, 2009). 
Table 3

Amount of straw, nitrogen and carbon accumulated during the 2012 season, in the Rhodic Hapludox, as affected by crop rotations. Botucatu, Brazil, 2012.

\begin{tabular}{|c|c|c|c|}
\hline \multirow{2}{*}{$\begin{array}{l}\text { Fall/winter } \\
\text { cover crops }\end{array}$} & \multicolumn{3}{|c|}{ Spring cover crops } \\
\hline & Pearl millet & Forage sorghum & Sunn hemp \\
\hline & \multicolumn{3}{|c|}{ Straw amount $\left(\mathrm{Mg} \mathrm{ha}^{-1}\right)$} \\
\hline Ruzigrass & 12986 Аа & $13688 \mathrm{Aa}$ & $14023 \mathrm{Aa}$ \\
\hline Grain sorghum & $8860 \mathrm{Ba}$ & $10239 \mathrm{Ba}$ & $9753 \mathrm{Ba}$ \\
\hline \multirow[t]{2}{*}{ Ruzigrass + grain sorghum } & $10602 \mathrm{Bb}$ & $11600 \mathrm{Bab}$ & 13013 Aa \\
\hline & \multicolumn{3}{|c|}{$\mathrm{N}$ accumulated in straw $\left(\mathrm{kg} \mathrm{ha}^{-1}\right)$} \\
\hline Ruzigrass & $166 \mathrm{Ab}$ & $235 \mathrm{Aa}$ & $262 \mathrm{Aa}$ \\
\hline Grain sorghum & $75 \mathrm{Cb}$ & $86 \mathrm{Cb}$ & $126 \mathrm{Ca}$ \\
\hline \multirow[t]{2}{*}{ Ruzigrass + Grain sorghum } & $131 \mathrm{Bc}$ & $166 \mathrm{Bb}$ & $229 \mathrm{Ba}$ \\
\hline & \multicolumn{3}{|c|}{$\mathrm{C}$ accumulated in straw $\left(\mathrm{kg} \mathrm{ha}^{-1}\right)$} \\
\hline Ruzigrass & $5574 \mathrm{Aa}$ & $5850 \mathrm{Aa}$ & $6045 \mathrm{Aa}$ \\
\hline Grain sorghum & $3881 \mathrm{Ba}$ & $4525 \mathrm{Ba}$ & $4256 \mathrm{Ba}$ \\
\hline Ruzigrass + grain sorghum & $4598 \mathrm{Bb}$ & 5139 ABab & $5471 \mathrm{Aa}$ \\
\hline
\end{tabular}

Means followed by different letters, upper-case letters within a column and lower-case letters within a row differ from each other by the paired $t$ test (LSD. $P<0.05$ ).

\section{Results}

The crop species used in both soil types had different composition of structural carbohydrates (lignin, hemicellulose, and cellulose), $\mathrm{C}$, and $\mathrm{N}$ (Table 2), which may interfere with residues' decay. In addition, crop rotations resulted in different quantities of dry matter, $\mathrm{C}$, and $\mathrm{N}$ in the straw (Table 3 ).

In the Rhodic Hapludox, the presence of ruzigrass resulted in a higher straw production, considering the total of three harvests (Table 3). Among the spring crops, sunn hemp had a higher production of straw only when cropped over the ruzigrass/ sorghum mixture. The presence of pearl millet was associated with a relatively low $\mathrm{N}$ input, while sunn hemp and ruzigrass with high $\mathrm{N}$ inputs (Table 3 ). The accumulation of $\mathrm{C}$ in the straw followed a similar pattern to that of the dry matter, and treatments with grain sorghum in fall/winter were always among those with the lowest $\mathrm{C}$ contribution to the soil. The highest contribution of $\mathrm{C}$ and $\mathrm{N}$ occurred from ruzigrass/sunn hemp (6045 and $262 \mathrm{~kg} \mathrm{ha}^{-1}$, respectively), while the lowest was observed with pearl millet/ grain sorghum (3881 and $75 \mathrm{~kg} \mathrm{ha}^{-1}$, respectively).

In the Typic Rhodudalf, fallow resulted in a relatively low straw produciton and lower $\mathrm{C}$ and $\mathrm{N}$ inputs as compared with the other treatments due to the absence of spring crops (Table 4). No differences were observed in dry matter yields between the spring crops or the fall/winter crops (Table 4). Sunn hemp resulted in greater annual inputs of $\mathrm{N}$, regardless the fall/winter crop, reaching a mean value of $293 \mathrm{~kg} \mathrm{ha}^{-1}$ of $\mathrm{N}$ (Table 4). Furthermore, sunn hemp resulted in a relatively higher $C$ input when grown after sunflower (Table 4). Among the fall/winter crops, it resulted in a relatively higher $C$ input compared with sunflower only when followed by fallow in the spring, an showing that the other spring crops compensated for the relatively higher $\mathrm{C}$ accumulation ability of triticale (Table 4).

Soil analysis revealed no significant interactions of the fall/ winter and spring crops. For this reason, only the main effects were compared and discussed. In the Rhodic Hapludox, only ruzigrass reduced $\mathrm{H}_{\mathrm{LIF}}$ at the $0-0.10 \mathrm{~m}$ soil depth (Table 5 ). In the Typic Rhodudalf, only at the $0-0.10 \mathrm{~m}$ soil depth, the TOC, MOC, $\mathrm{N}_{\mathrm{SMB}}$, the $\mathrm{C} / \mathrm{N}$ ratio (Table 6 ), and the $\mathrm{N}_{\mathrm{SMB}} / \mathrm{TN}$ ratio (Table 7 ) were higher with the triticale, but the $\mathrm{H}_{\text {LIF }}$ (Table 6) was higher where sunflower was grown in fall/winter.

In the Rhodic Hapludox, sunn hemp was always among the species that significantly improved the soil, especially at 0 0.10 and $0.10-0.20 \mathrm{~m}$ soil depths, as compared with pearl millet. At the $0-0.10 \mathrm{~m}$ soil depth, sunn hemp and forage sorghum resulted in higher TOC, MOC (Table 5) and $\mathrm{C}_{\mathrm{SMB}}$ (Table 7). At the same soil depth, the $\mathrm{N}_{\mathrm{SMB}}$ and $\mathrm{N}_{\mathrm{SMB}} / \mathrm{TN}$ ratio (Table 7 ) were higher where sunn hemp was grown in spring. At $0.10-0.20 \mathrm{~m}$, sunn hemp and forage sorghum resulted in higher TN, TOC, POC, and MOC values, and at $0.20-0.40 \mathrm{~m}$ the TN was greater with forage sorghum, but was not significantly different from sunn hemp (Table 5).

In the Typic Rhodudalf, sunn hemp and pearl millet resulted in higher TN, TOC, POC, and $\mathrm{C}_{\mathrm{SMB}}$, while fallow decreased them at the 0-0.10 m soil depth (Table 6). At the same depth, sunn hemp decreased $\mathrm{H}_{\mathrm{LIF}}$, while the results obtained with forage sorghum were similar to fallow (Table 6 ). $\mathrm{H}_{\text {LIF }}$ from sunn hemp was also low at $0.10-0.20$ and $0.20-0.40$ soil depths. At $0.10-0.20 \mathrm{~m}$ soil depth, sunn hemp resulted in high concentrations of $\mathrm{N}$ and $\mathrm{C}$ in the soil, but the difference was not significant from those obtained with forage sorghum and fallow, except for POC. It was observed that POC and the POC/TOC ratio were greater with a legume as spring crop, showing an accumulation of SOM of higher lability (Table 6). Sunn hemp was also among the species that resulted in higher TN,

Table 4

Amount of straw, nitrogen and carbon accumulated during the 2012 season, in the Typic Rhodudalf, as affected by cropping systems. Botucatu, Brazil, 2012.

\begin{tabular}{|c|c|c|c|c|}
\hline Fall/winter & \multicolumn{4}{|c|}{ Spring cover crops } \\
\hline Cover crops & \multicolumn{3}{|c|}{ Straw amount $\left(\mathrm{Mg} \mathrm{ha}^{-1}\right)$} & Forage Sorghum \\
\hline Sunflower & $14287 \mathrm{Aa}$ & $7437 \mathrm{Ab}$ & $12761 \mathrm{Aa}$ & $12734 \mathrm{Aa}$ \\
\hline Triticale & \multicolumn{4}{|c|}{$\mathrm{N}$ accumulated in straw $\left(\mathrm{kg} \mathrm{ha}^{-1}\right)$} \\
\hline Sunflower & $293 \mathrm{Aa}$ & $77 \mathrm{Ad}$ & $248 \mathrm{Ab}$ & $205 \mathrm{Ac}$ \\
\hline Triticale & \multicolumn{4}{|c|}{$\mathrm{C}$ aaccumulated in straw $\left(\mathrm{kg} \mathrm{ha}^{-1}\right)$} \\
\hline Sunflower & $5997 \mathrm{Aa}$ & $3133 \mathrm{Bc}$ & $5133 \mathrm{Ab}$ & $5242 \mathrm{Ab}$ \\
\hline Triticale & $5858 \mathrm{Aa}$ & $4076 \mathrm{Ab}$ & $5902 \mathrm{Aa}$ & $5307 \mathrm{Aa}$ \\
\hline
\end{tabular}

Means followed by different letters, upper-case letters within a column and lower-case letters within a row differ from each other by the paired $t$ test (LSD. $P<0.05$ ). 
Table 5

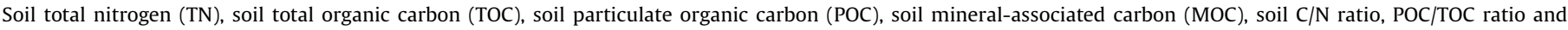
humification degree of soil organic matter $\left(\mathrm{H}_{\mathrm{LIF}}\right)$ as affected by soil depth and cover crops. Rhodic Hapludox, Botucatu, Brazil.

\begin{tabular}{|c|c|c|c|c|c|c|c|}
\hline \multirow[t]{2}{*}{ Crop } & TN & TOC & POC & MOC & $\mathrm{C} / \mathrm{N}$ & $\mathrm{POC} / \mathrm{TOC}$ & $\mathrm{H}_{\mathrm{LIF}}$ \\
\hline & \multicolumn{4}{|c|}{-----------------g kg $\mathrm{gg}^{-1}--------------$} & \multicolumn{3}{|c|}{-----\%----ー } \\
\hline \multicolumn{8}{|l|}{$0-0.10 \mathrm{~m}$} \\
\hline \multicolumn{8}{|l|}{ Fall/Winter } \\
\hline Ruzigrass & $0.97 \mathrm{a}$ & $14.14 \mathrm{a}$ & $2.17 \mathrm{a}$ & $11.96 \mathrm{a}$ & $14.95 \mathrm{a}$ & $15.38 \mathrm{a}$ & $1017.7 \mathrm{~b}$ \\
\hline Grain sorghum & $0.93 \mathrm{a}$ & $13.83 \mathrm{a}$ & $1.85 \mathrm{a}$ & $11.98 \mathrm{a}$ & $15.16 \mathrm{a}$ & $13.31 \mathrm{a}$ & $1150.2 \mathrm{a}$ \\
\hline Sorghum + ruzigrass & $1.02 \mathrm{a}$ & $14.10 \mathrm{a}$ & $1.94 \mathrm{a}$ & $12.15 \mathrm{a}$ & $14.29 \mathrm{a}$ & $13.74 \mathrm{a}$ & $1147.5 \mathrm{a}$ \\
\hline \multicolumn{8}{|l|}{ Spring } \\
\hline Sunn hemp & $0.99 \mathrm{~A}$ & $14.38 \mathrm{~A}$ & $2.02 \mathrm{~A}$ & $12.36 \mathrm{~A}$ & $14.96 \mathrm{~A}$ & $14.01 \mathrm{~A}$ & $1100.8 \mathrm{~A}$ \\
\hline Pearl millet & $0.96 \mathrm{~A}$ & $13.52 \mathrm{~B}$ & $1.84 \mathrm{~A}$ & $11.67 \mathrm{~B}$ & $14.44 \mathrm{~A}$ & $13.56 \mathrm{~A}$ & $1146.5 \mathrm{~A}$ \\
\hline Forage sorghum & $0.97 \mathrm{~A}$ & $14.18 \mathrm{AB}$ & $2.11 \mathrm{~A}$ & $12.06 \mathrm{AB}$ & $15.00 \mathrm{~A}$ & $14.86 \mathrm{~A}$ & $1068.1 \mathrm{~A}$ \\
\hline \multicolumn{8}{|l|}{$0.10-0.20 \mathrm{~m}$} \\
\hline \multicolumn{8}{|l|}{ Fall/Winter } \\
\hline Ruzigrass & $0.72 \mathrm{a}$ & $10.89 \mathrm{a}$ & $0.58 \mathrm{a}$ & $10.32 \mathrm{a}$ & $16.13 \mathrm{a}$ & $5.36 \mathrm{a}$ & $1403.6 \mathrm{a}$ \\
\hline Grain sorghum & $0.71 \mathrm{a}$ & $10.49 \mathrm{a}$ & $0.62 \mathrm{a}$ & $9.87 \mathrm{a}$ & $15.74 \mathrm{a}$ & $5.96 \mathrm{a}$ & $1408.1 \mathrm{a}$ \\
\hline Sorghum + ruzigrass & $0.76 \mathrm{a}$ & $10.83 \mathrm{a}$ & $0.63 a$ & $10.19 \mathrm{a}$ & $15.08 \mathrm{a}$ & $5.89 \mathrm{a}$ & $1405.1 \mathrm{a}$ \\
\hline \multicolumn{8}{|l|}{ Spring } \\
\hline Sunn hemp & $0.74 \mathrm{~A}$ & $11.00 \mathrm{~A}$ & $0.60 \mathrm{AB}$ & $10.40 \mathrm{~A}$ & $15.77 \mathrm{~A}$ & $5.49 \mathrm{~A}$ & $1397.3 \mathrm{~A}$ \\
\hline Pearl millet & $0.68 \mathrm{~B}$ & $10.31 \mathrm{~B}$ & $0.55 \mathrm{~B}$ & 9.76 B & $15.96 \mathrm{~A}$ & $5.38 \mathrm{~A}$ & $1464.7 \mathrm{~A}$ \\
\hline Forage Sorghum & $0.76 \mathrm{~A}$ & $10.91 \mathrm{AB}$ & $0.68 \mathrm{~A}$ & $10.22 \mathrm{AB}$ & $15.23 \mathrm{~A}$ & $6.34 \mathrm{~A}$ & $1354.9 \mathrm{~A}$ \\
\hline \multicolumn{8}{|l|}{$0.20-0.40 \mathrm{~m}$} \\
\hline \multicolumn{8}{|l|}{ Fall/Winter } \\
\hline Ruzigrass & $0.64 \mathrm{a}$ & $9.62 \mathrm{a}$ & $0.38 \mathrm{a}$ & $9.24 \mathrm{a}$ & $16.01 \mathrm{a}$ & $3.94 \mathrm{a}$ & $1709.0 \mathrm{a}$ \\
\hline Grain sorghum & $0.61 \mathrm{a}$ & $9.34 \mathrm{a}$ & $0.35 \mathrm{a}$ & 8.99 a & $16.26 \mathrm{a}$ & $3.76 \mathrm{a}$ & $1677.3 \mathrm{a}$ \\
\hline Sorghum + ruzigrass & $0.67 \mathrm{a}$ & $9.21 \mathrm{a}$ & $0.39 \mathrm{a}$ & $8.83 \mathrm{a}$ & $14.39 \mathrm{a}$ & $4.22 \mathrm{a}$ & $1757.8 \mathrm{a}$ \\
\hline \multicolumn{8}{|l|}{ Spring } \\
\hline Sunn hemp & $0.64 \mathrm{AB}$ & $9.40 \mathrm{~A}$ & $0.38 \mathrm{~A}$ & $9.02 \mathrm{~A}$ & $15.66 \mathrm{~A}$ & $4.10 \mathrm{~A}$ & $1676.2 \mathrm{~A}$ \\
\hline Pearl millet & $0.62 \mathrm{~B}$ & $9.40 \mathrm{~A}$ & $0.37 \mathrm{~A}$ & $9.03 \mathrm{~A}$ & $16.13 \mathrm{~A}$ & $3.91 \mathrm{~A}$ & $1754.8 \mathrm{~A}$ \\
\hline Forage sorghum & $0.66 \mathrm{~A}$ & $9.38 \mathrm{~A}$ & $0.37 \mathrm{~A}$ & $9.01 \mathrm{~A}$ & $14.87 \mathrm{~A}$ & $3.91 \mathrm{~A}$ & $1713.1 \mathrm{~A}$ \\
\hline \multicolumn{8}{|l|}{$0.40-0.60 \mathrm{~m}$} \\
\hline \multicolumn{8}{|l|}{ Fall/Winter } \\
\hline Ruzigrass & $0.60 \mathrm{a}$ & $11.12 \mathrm{a}$ & $0.53 \mathrm{a}$ & $10.59 \mathrm{a}$ & $20.18 \mathrm{a}$ & $4.75 \mathrm{a}$ & $1478.3 \mathrm{a}$ \\
\hline Grain sorghum & $0.61 \mathrm{a}$ & $11.12 \mathrm{a}$ & $0.53 \mathrm{a}$ & $10.59 \mathrm{a}$ & $19.47 \mathrm{a}$ & $4.81 \mathrm{a}$ & $1503.8 \mathrm{a}$ \\
\hline Sorghum + ruzigrass & $0.63 \mathrm{a}$ & $10.86 \mathrm{a}$ & $0.58 \mathrm{a}$ & $10.27 \mathrm{a}$ & $18.78 \mathrm{a}$ & $5.23 \mathrm{a}$ & $1435.7 \mathrm{a}$ \\
\hline \multicolumn{8}{|l|}{ Spring } \\
\hline Sunn hemp & $0.61 \mathrm{~A}$ & $11.37 \mathrm{~A}$ & $0.57 \mathrm{~A}$ & $10.80 \mathrm{~A}$ & $20.84 \mathrm{~A}$ & $5.02 \mathrm{~A}$ & $1466.8 \mathrm{~A}$ \\
\hline Pearl millet & $0.61 \mathrm{~A}$ & $11.19 \mathrm{~A}$ & $0.54 \mathrm{~A}$ & $10.64 \mathrm{~A}$ & $19.72 \mathrm{AB}$ & $4.80 \mathrm{~A}$ & $1411.1 \mathrm{~A}$ \\
\hline Forage sorghum & $0.63 \mathrm{~A}$ & $10.55 \mathrm{~A}$ & $0.54 \mathrm{~A}$ & $10.00 \mathrm{~A}$ & $17.88 \mathrm{~B}$ & $4.98 \mathrm{~A}$ & $1539.9 \mathrm{~A}$ \\
\hline
\end{tabular}

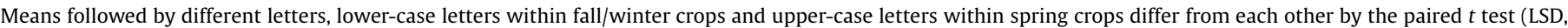
$P<0.05)$.

TOC, and POC at $0.20-0.40 \mathrm{~m}$ soil depth. At $0.40-0.60 \mathrm{~m}$, sunn hemp and pearl millet yielded the highest TN; however, it was found that the soil $C$ concentrations were higher with Gramineae (pearl millet and forage sorghum), i.e., TOC, POC (mainly with forage sorghum), and MOC (mainly with millet), affecting the $\mathrm{C} / \mathrm{N}$ ratio of the soil and lability of SOM due to the relatively high POC and TOC values and low $\mathrm{H}_{\mathrm{LIF}}$ values (Table 6).

The mean $\mathrm{C} / \mathrm{N}$ ratio ranged between 14.8 and 19.5 in the Rhodic Hapludox and increased with depth (Table 5), while it was approximately 10.0 in the Typic Rhodudalf, regardless of the soil depth. The higher $\mathrm{C} / \mathrm{N}$ ratio in the Rhodic Hapludox can be explained by the lower TN (approximately 50\%), compared with the Typic Rhodudalf, despite the higher TOC (approximately 25\%) in the latter. In both soil types, $\mathrm{H}_{\mathrm{LIF}}$ increased with soil depth (Tables 5 and 6), which is attributed to the higher input of labile organic matter on the surface. At $0-0.10 \mathrm{~m}$ soil depth, $\mathrm{C}_{\mathrm{SMB}}$ ranged between 197 and $229 \mathrm{mg} \mathrm{kg}^{-1}$ (Table 7). In the Typic Rhodudalf, the mean $\mathrm{C}_{\mathrm{SMB}}$ in the $0-0.10 \mathrm{~m}$ depth ranged from 235 to $300 \mathrm{mg} \mathrm{kg}^{-1}$, with an overall mean of $259 \mathrm{mg} \mathrm{kg}^{-1}$ (Table 7). In both soil types, there were differences in $\mathrm{C}_{\mathrm{SMB}}$ only between the spring crops. Sunn hemp was associated with relatively higher $C_{S M B}$ values as compared with forage sorghum and fallow in the Typic Rhodudalf and pearl millet in the Rhodic Hapludox (Table 7). No differences were found for the $\mathrm{C}_{\mathrm{SMB}} / \mathrm{TOC}$ ratio (approximately $1.5 \%$ on average).

In both soils, $\mathrm{N}_{\mathrm{SMB}}$ ranged between 15 and $30 \mathrm{mg} \mathrm{kg}^{-1}$ and the $\mathrm{N}_{\mathrm{SMB}} / \mathrm{TN}$ ratio between 1 and $3 \%$. In the Rhodic Hapludox, $\mathrm{N}_{\mathrm{SMB}}$ differed significantly only between the spring crops. Among those, the highest concentration was associated with sunn hemp, which also showed the highest $\mathrm{N}_{\mathrm{SMB}} / \mathrm{TN}$ ratio (Table 7 ). In the Typic Rhodudalf, $\mathrm{N}_{\mathrm{SMB}}$ was significantly different only between the fall/ winter crops. Out of those, triticale was associated with the highest $\mathrm{N}_{\mathrm{SMB}}$ and $\mathrm{N}_{\mathrm{SMB}} / \mathrm{TN}$ ratio (Table 7 ).

\section{Discussion}

The input of dry matter, $\mathrm{C}$, and $\mathrm{N}$ had positive effects on the accumulation of TOC, POC, MOC, and TN in the soil, especially in the Typic Rhodudalf. The absence of $\mathrm{N}$ input and plant residues in the spring, as observed in the chiseled/fallow treatment, limited the accumulation of TOC and its fractions, although these effects were much more evident at $0-0.10 \mathrm{~m}$ soil depth. These results are in agreement with reports demonstrating the importance of the positive balance of $\mathrm{N}$ in tropical and subtropical agro-ecosystems, since it is paramount for C sequestering (Sisti et al., 2004; Boddey et al., 2010). Thus, SOM increase is conditioned by the input of $\mathrm{N}$ into the soil, which leads to a higher production of phytomass and plant residue in the system and also allows the direct delivery of $\mathrm{N}_{\mathrm{SMB}}$ to the soil. However, these effects are also influenced by edaphic factors such as the soil texture, because high clay contents lead to further stabilization of SOM and decreases N and C losses (Wattel-Koekkoek et al., 2001).

In the Rhodic Hapludox, TN was low, which was in agreement with the results of Souza and Melo (2000) obtained under similar 
Table 6

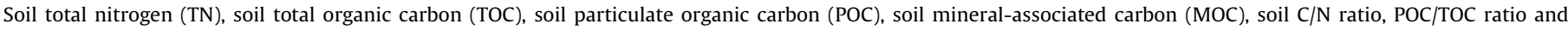
humification degree of soil organic matter $\left(\mathrm{H}_{\mathrm{LIF}}\right)$, as affected by cropping systes and soil depth. Typic Rhodudalf, Botucatu, Brazil.

\begin{tabular}{|c|c|c|c|c|c|c|c|}
\hline Crop & TN & \multicolumn{2}{|c|}{--------------- $\mathrm{g} \mathrm{kg}^{-1}--------------$} & MOC & $\begin{array}{l}\mathrm{C} / \mathrm{N} \\
---\%-\end{array}$ & POC/TOC & $\mathrm{H}_{\mathrm{LIF}}$ \\
\hline \multicolumn{8}{|l|}{$0-0.10 \mathrm{~m}$} \\
\hline \multicolumn{8}{|l|}{ Fall/Winter } \\
\hline Sunflower & $1.86 \mathrm{a}$ & $18.55 \mathrm{~b}$ & $3.08 \mathrm{a}$ & $15.47 \mathrm{~b}$ & $9.96 \mathrm{~b}$ & $16.57 \mathrm{a}$ & $1215.3 \mathrm{a}$ \\
\hline Triticale & $1.92 \mathrm{a}$ & $19.60 \mathrm{a}$ & $3.18 \mathrm{a}$ & $16.42 \mathrm{a}$ & $10.23 \mathrm{a}$ & $16.23 \mathrm{a}$ & $1102.7 \mathrm{~b}$ \\
\hline \multicolumn{8}{|l|}{ Spring } \\
\hline Sunn hemp & $1.96 \mathrm{~A}$ & $19.82 \mathrm{~A}$ & $3.41 \mathrm{~A}$ & $16.41 \mathrm{~A}$ & $10.10 \mathrm{~A}$ & $17.27 \mathrm{~A}$ & $1090.5 \mathrm{~B}$ \\
\hline Pearl millet & $1.95 \mathrm{~A}$ & $19.50 \mathrm{AB}$ & $3.24 \mathrm{AB}$ & $16.26 \mathrm{~A}$ & $10.01 \mathrm{~A}$ & $16.58 \mathrm{~A}$ & $1170.6 \mathrm{~A}$ \\
\hline Fallow/chisel & $1.79 \mathrm{~B}$ & $18.16 \mathrm{C}$ & $2.89 \mathrm{C}$ & $15.27 \mathrm{~B}$ & $10.12 \mathrm{~A}$ & $15.95 \mathrm{~A}$ & 1196.6 A \\
\hline Forage sorghum & $1.85 \mathrm{~B}$ & $18.81 \mathrm{BC}$ & $2.98 \mathrm{BC}$ & $15.83 \mathrm{AB}$ & $10.14 \mathrm{~A}$ & $15.81 \mathrm{~A}$ & $1178.2 \mathrm{~A}$ \\
\hline \multicolumn{8}{|l|}{$0.10-0.20 \mathrm{~m}$} \\
\hline \multicolumn{8}{|l|}{ Fall/Winter } \\
\hline Sunflower & $1.56 \mathrm{a}$ & $14.58 \mathrm{a}$ & $1.26 \mathrm{a}$ & $13.32 \mathrm{a}$ & $9.38 \mathrm{a}$ & $8.63 \mathrm{a}$ & $1464.9 \mathrm{a}$ \\
\hline Triticale & $1.54 \mathrm{a}$ & $14.73 \mathrm{a}$ & $1.30 \mathrm{a}$ & $13.43 \mathrm{a}$ & $9.56 \mathrm{a}$ & $8.78 \mathrm{a}$ & $1420.9 \mathrm{a}$ \\
\hline \multicolumn{8}{|l|}{ Spring } \\
\hline Sunn hemp & $1.61 \mathrm{~A}$ & $15.21 \mathrm{~A}$ & $1.45 \mathrm{~A}$ & $13.76 \mathrm{~A}$ & $9.47 \mathrm{~A}$ & $9.55 \mathrm{~A}$ & 1377.7 B \\
\hline Pearl millet & $1.48 \mathrm{~B}$ & $13.85 \mathrm{~B}$ & $1.16 \mathrm{~B}$ & $12.69 \mathrm{~B}$ & $9.37 \mathrm{~A}$ & $8.39 \mathrm{~B}$ & $1499.8 \mathrm{~A}$ \\
\hline Fallow/chisel & $1.57 \mathrm{~A}$ & $14.99 \mathrm{~A}$ & $1.25 \mathrm{~B}$ & $13.74 \mathrm{~A}$ & $9.54 \mathrm{~A}$ & $8.36 \mathrm{~B}$ & $1454.3 \mathrm{AB}$ \\
\hline Forage sorghum & $1.54 \mathrm{AB}$ & $14.56 \mathrm{AB}$ & $1.24 \mathrm{~B}$ & $13.32 \mathrm{AB}$ & $9.48 \mathrm{~A}$ & $8.52 \mathrm{~B}$ & $1439.9 \mathrm{AB}$ \\
\hline \multicolumn{8}{|l|}{$0.20-0.40 \mathrm{~m}$} \\
\hline \multicolumn{8}{|l|}{ Fall/Winter } \\
\hline Sunflower & $1.36 \mathrm{a}$ & $12.48 \mathrm{a}$ & $0.82 \mathrm{a}$ & $11.65 \mathrm{a}$ & $9.17 \mathrm{a}$ & $6.63 \mathrm{a}$ & $1729.7 \mathrm{a}$ \\
\hline Triticale & $1.36 \mathrm{a}$ & $12.49 \mathrm{a}$ & $0.82 \mathrm{a}$ & $11.66 \mathrm{a}$ & $9.16 \mathrm{a}$ & $6.56 \mathrm{a}$ & $1703.2 \mathrm{a}$ \\
\hline \multicolumn{8}{|l|}{ Spring } \\
\hline Sunn hemp & $1.41 \mathrm{~A}$ & $12.75 \mathrm{~A}$ & $0.90 \mathrm{~A}$ & $11.85 \mathrm{~A}$ & $9.06 \mathrm{~A}$ & $7.08 \mathrm{~A}$ & 1647.9 B \\
\hline Pearl millet & $1.39 \mathrm{AB}$ & $12.74 \mathrm{~A}$ & $0.81 \mathrm{AB}$ & $11.92 \mathrm{~A}$ & $9.19 \mathrm{~A}$ & $6.38 \mathrm{~A}$ & $1686.4 \mathrm{AB}$ \\
\hline Fallow/chisel & $1.36 \mathrm{AB}$ & $12.48 \mathrm{AB}$ & $0.83 \mathrm{AB}$ & $11.65 \mathrm{~A}$ & $9.17 \mathrm{~A}$ & $6.63 \mathrm{~A}$ & 1777.6 A \\
\hline Forage sorghum & $1.27 \mathrm{~B}$ & $11.88 \mathrm{~B}$ & $0.74 \mathrm{~B}$ & $11.14 \mathrm{~A}$ & $9.26 \mathrm{~A}$ & $6.27 \mathrm{~A}$ & $1754.1 \mathrm{AB}$ \\
\hline \multicolumn{8}{|l|}{$0.40-0.60 \mathrm{~m}$} \\
\hline \multicolumn{8}{|l|}{ Fall/Winter } \\
\hline Sunflower & $1.18 \mathrm{a}$ & $11.88 \mathrm{a}$ & $0.76 \mathrm{a}$ & $11.12 \mathrm{a}$ & $10.10 \mathrm{a}$ & $6.37 \mathrm{a}$ & $1665.0 \mathrm{a}$ \\
\hline Triticale & $1.19 \mathrm{a}$ & $12.32 \mathrm{a}$ & $0.83 a$ & $11.49 \mathrm{a}$ & $10.39 \mathrm{a}$ & $6.67 \mathrm{a}$ & $1609.2 \mathrm{a}$ \\
\hline \multicolumn{8}{|l|}{ Spring } \\
\hline Sunn hemp & $1.22 \mathrm{~A}$ & $12.07 \mathrm{AB}$ & $0.73 \mathrm{AB}$ & $11.35 \mathrm{AB}$ & $9.91 \mathrm{~B}$ & $5.98 \mathrm{~B}$ & $1738.2 \mathrm{AB}$ \\
\hline Pearl millet & $1.21 \mathrm{~A}$ & $12.49 \mathrm{~A}$ & $0.85 \mathrm{AB}$ & $11.64 \mathrm{~A}$ & $10.32 \mathrm{AB}$ & $6.84 \mathrm{AB}$ & $1566.8 \mathrm{BC}$ \\
\hline Fallow/chisel & $1.15 \mathrm{~B}$ & $11.55 \mathrm{~B}$ & 0.64 B & $10.90 \mathrm{~B}$ & $10.03 \mathrm{AB}$ & $5.55 \mathrm{~B}$ & $1788.9 \mathrm{~A}$ \\
\hline Forage sorghum & $1.15 \mathrm{~B}$ & $12.29 \mathrm{~A}$ & $0.95 \mathrm{~A}$ & $11.34 \mathrm{AB}$ & $10.72 \mathrm{~A}$ & $7.70 \mathrm{~A}$ & $1454.6 \mathrm{C}$ \\
\hline
\end{tabular}

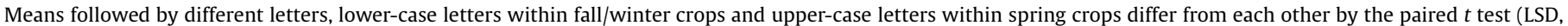
$P<0.05)$.

Table 7

Soil microbial biomass carbon $\left(\mathrm{C}_{\mathrm{SMB}}\right)$, soil microbial biomass nitrogen $\left(\mathrm{N}_{\mathrm{SMB}}\right), \mathrm{C}_{\mathrm{SMB}} /$ TOC ratio and $\mathrm{N}_{\mathrm{SMB}} / \mathrm{TN}$ ratio, at the $0-0.10 \mathrm{~m}$ soil depth, as affected by crop rotations and cropping systems. Rhodic Hapludox and Typic Rhodudalf, Botucatu, Brazil, 2013.

\begin{tabular}{|c|c|c|c|c|}
\hline Crop rotation & \multicolumn{2}{|c|}{-----mg kg ${ }^{-1}---$} & \multicolumn{2}{|c|}{---------\%-------- } \\
\hline \multicolumn{5}{|l|}{ Rhodic Hapludox } \\
\hline \multicolumn{5}{|l|}{ Fall/Winter } \\
\hline Ruzigrass & 207.5 a & $27.8 \mathrm{a}$ & $1.47 \mathrm{a}$ & $2.96 \mathrm{a}$ \\
\hline Grain Sorghum & $210.1 \mathrm{a}$ & 20.6 a & $1.51 \mathrm{a}$ & $2.18 \mathrm{a}$ \\
\hline Sorghum+Ruzigrass & $224.3 \mathrm{a}$ & $18.6 \mathrm{a}$ & $1.59 \mathrm{a}$ & $1.87 \mathrm{a}$ \\
\hline \multicolumn{5}{|l|}{ Spring } \\
\hline Sunn Hemp & $229.8 \mathrm{~A}$ & $28.8 \mathrm{~A}$ & $1.60 \mathrm{~A}$ & $2.98 \mathrm{~A}$ \\
\hline Pearl Millet & $197.5 \mathrm{~B}$ & $17.7 \mathrm{~B}$ & $1.46 \mathrm{~A}$ & $1.84 \mathrm{~B}$ \\
\hline Forage Sorghum & $214.7 \mathrm{AB}$ & $20.5 \mathrm{~B}$ & $1.52 \mathrm{~A}$ & $2.19 \mathrm{~B}$ \\
\hline \multicolumn{5}{|l|}{ Typic Rhodudalf } \\
\hline \multicolumn{5}{|l|}{ Fall/Winter } \\
\hline Sunflower & $257.4 \mathrm{a}$ & $18.5 \mathrm{~b}$ & $1.39 \mathrm{a}$ & $0.99 \mathrm{~b}$ \\
\hline Triticale & $262.4 \mathrm{a}$ & $26.1 \mathrm{a}$ & $1.34 \mathrm{a}$ & $1.37 \mathrm{a}$ \\
\hline \multicolumn{5}{|l|}{ Spring } \\
\hline Sunn Hemp & $300.4 \mathrm{~A}$ & $22.6 \mathrm{~A}$ & $1.53 \mathrm{~A}$ & $1.26 \mathrm{~A}$ \\
\hline Pearl Millet & $265.0 \mathrm{AB}$ & $23.7 \mathrm{~A}$ & $1.37 \mathrm{~A}$ & $1.38 \mathrm{~A}$ \\
\hline Fallow/chisel & 239.4 B & $19.2 \mathrm{~A}$ & $1.32 \mathrm{~A}$ & $1.06 \mathrm{~A}$ \\
\hline Forage Sorghum & $234.8 \mathrm{~B}$ & $23.8 \mathrm{~A}$ & $1.24 \mathrm{~A}$ & $1.03 \mathrm{~A}$ \\
\hline
\end{tabular}

Means followed by different letters, lower-case letters within fall/winter crops and upper-case letters within spring crops differ from each other by the paired $t$ test (LSD, $P<0.05$ ). soil and climate. The low TN and the absence of significant differences between the treatments at the $0-0.10 \mathrm{~m}$ soil depth show that organic $\mathrm{N}$ was not sufficiently protected in the soil, allowing its loss by leaching or gaseous emissions. The relatively high inputs of dry matter and $\mathrm{N}$ supplied by sunn hemp residues in the spring and ruzigrass in fall/winter were not enough to increase TN at the $0-0.10 \mathrm{~m}$ soil depth. At $0.10-0.20 \mathrm{~m}$ soil depth, differences in the straw, $\mathrm{C}$, and $\mathrm{N}$ inputs were reflected on the $\mathrm{C}$ and $\mathrm{N}$ concentrations in the soil, due to the high clay content.

In the Typic Rhodudalf, the $\mathrm{N}$ and dry matter inputs by plant residues had a stronger effect on the increase of $\mathrm{TN}$ in the soil at all depths, because of the higher clay content (Table 6). The higher soil TN occurred with the use of sunn hemp and pearl millet, except for the $0.10-0.20 \mathrm{~m}$ depth, and were in accordance with the highest $\mathrm{N}$ inputs in crop rotations with these species (Table 4). A relatively higher $\mathrm{N}$ input from sunn hemp compared to millet and sorghum had also been previously observed in the field (Perin et al., 2006). Kappes et al. (2013) reported a positive effect of sunn hemp on corn yields. Thus, the relatively high $\mathrm{N}$ input from sunn hemp, of which more than 50\% originates from biological fixation (Perin et al. 2006), contributes to the long-term cycling and maintenance of TN in the soil.

In both soil types, the higher concentrations of TOC with the introduction of sunn hemp in the crop rotation shows the importance of biologically fixed $\mathrm{N}$ for the accumulation of organic 
C. However, while in the Rhodic Hapludox sunn hemp had a strong effect on TOC, but limited on MOC, in the Typic Rhodudalf, the effect was strong both on POC and MOC. The relatively higher annual inputs of $C$ and $N$ by crop residues (Tables 3 and 4 ) and the relatively higher lignin concentrations in this legume species (Table 2) might contribute to the accumulation of organic matter without mineral nitrogen fertilization, optimizing the microbial metabolism and maximizing the input of polyphenolic chains (Gama-Rodrigues et al., 2005; Stevenson, 1994). The lack of differences between the $\mathrm{C} / \mathrm{N}$ ratio in both soil types at $0-0.10,0.10-$ $0.20,0.20-0.40 \mathrm{~m}$ soil depths (Tables 5 and 6 ) showed similar variations between TN and TOC. However, this relationship was not a satisfactory indicator of the main effects of spring crops in this study.

Because of the high ability of Urochloa spp. to produce dry matter and take up $\mathrm{N}$, and also considering a possible biological $\mathrm{N}$ fixation (Boddey and Victoria, 1986), it was expected that ruzigrass would increase TOC in the soil, which was not observed (Table 5). These results are in agreement with the study of Garcia et al. (2013), who also reported no effect of ruzigrass on POC and TOC up to $0.10 \mathrm{~m}$ soil depth. Ruzigrass showed a high $\mathrm{N}$ concentration in the tissues, similar to that of sunn hemp (Table 2), but it did not result in higher TN in the soil. Although the presence of ruzigrass in the crop rotation resulted in higher annual accumulation of dry matter, $\mathrm{C}$, and $\mathrm{N}$ in the straw (Table 3 ), the higher losses of $\mathrm{CO}_{2}$ and $\mathrm{N}_{2} \mathrm{O}$ from the soil into the atmosphere might hinder its direct effect on the accumulation of TOC.

Calonego and Rosolem (2008) observed slightly higher average concentrations of SOM at 0-0.05 $\mathrm{m}$ soil depth with the use of triticale and sunn hemp than others spring and fall/winter crops, respectively, in a Typic Rhodudalf. These results show that both plant species favor the increase in SOM, although the differences between the fall/winter and spring crops were not significant. Thus, the effect of crop rotation on SOM under NT might require relatively long periods of experimentation to be observed. At $0.40-$ $0.60 \mathrm{~m}$ soil depth, cover crops, especially the grasses, resulted in higher TOC compared with chisel/fallow (Table 6), reflecting a positive effect of the root system on $\mathrm{C}$ input (Puget and Drinkwater, 2001). In addition, the release of soluble C compounds (Wright et al., 2007 and Boddey et al., 2010) could be an important mechanism of $C$ redistribution in the soil profile.

The introduction of fall/winter grasses was associated with a decrease in $\mathrm{H}_{\text {LIF }}$ at the $0-0.10 \mathrm{~m}$ soil depth. The relatively lower $\mathrm{H}_{\text {LIF }}$ from ruzigrass at this soil depth in the Rhodic Hapludox revealed the higher influence of this species on the straw input (Table 3). However, the lower $\mathrm{H}_{\mathrm{LIF}}$, compared with grain sorghum and sorghum/ruzigrass, was not associated with higher values of POC or the POC/TOC ratio (Table 5), as reported by Castro et al. (2015). In the Typic Rhodudalf, a relatively lower $\mathrm{H}_{\mathrm{LIF}}$ under triticale, compared with sunflower (Table 6), was expected, considering the higher TOC concentration, due to its greater capacity to accumulate $C$ in the residues (Table 4 ) and its fasciculate root system (Calonego and Rosolem, 2010). Since the relatively higher TOC from triticale occurred due to MOC and not POC, the possibility of re-synthesis (Stevenson, 1994) from the plant residues deposited in the soil over the 10-year period might effectively influence the accumulation of recalcitrant organic matter.

In the Typic Rhodudalf, the relatively low $\mathrm{H}_{\mathrm{LIF}}$ values with sunn hemp at $0-0.10$ and $0.10-0.20 \mathrm{~m}$ soil depths were in accordance with the relatively higher POC and POC/TOC ratio (Table 6). At $0.40-0.60 \mathrm{~m}$ soil depth, the relatively lower $\mathrm{H}_{\mathrm{LIF}}$ values were observed from spring grasses, possibly due to the effective root growth of these species at higher depths (Calonego and Rosolem, 2010), highlighting the importance of crop residues and light organic matter. The relatively higher $\mathrm{H}_{\mathrm{LIF}}$ observed with sunn hemp at $0.40-0.60 \mathrm{~m}$ soil depth showed that its effect on reducing the degree of humification was restricted to the topsoil layers, possibly due to its less effective root growth at lower depths (Calonego and Rosolem, 2010). These results did not differ significantly from the chislel/fallow treatment (Table 6). In both soil types, the absence of differences in $\mathrm{H}_{\mathrm{LIF}}$ between the spring grasses showed a similar behavior of these species in the humification process of SOM. In the Rhodic Hapludox, the absence of differences between $\mathrm{H}_{\text {LIF }}$ values at different soil depths shows that the effect of sunn hemp on TOC and MOC was not sufficient to significantly alter the humification degree of the soil.

The relatively higher input of residues and $\mathrm{N}$ from sunn hemp (Tables 3 and 4) resulted in higher $\mathrm{C}_{\mathrm{SMB}}$ in both soils (Table 7) and higher $\mathrm{N}_{\mathrm{SMB}}$ in the Rhodic Hapludox (Table 7), in which TN was lower. The $\mathrm{C}_{\mathrm{SMB}} / \mathrm{TOC}$ ratio was lower than the previously reported range of $2-5 \%$, while the $\mathrm{N}_{\mathrm{SMB}} / \mathrm{TN}$ ratio was close to the lower limit of the previously reported range of $1-5 \%$ in these soil types (Sparling, 1992). It is possible that in our study the microbial biomass was under environmental stress due to $\mathrm{N}$ deficiency in the system (Schimel et al., 2007; Mooshammer et al., 2014).

In the Rhodic Hapludoxl, the relatively higher $\mathrm{N}_{\mathrm{SMB}} / \mathrm{TN}$ ratio in the soil with sunn hemp (Table 7 ) suggests that the $\mathrm{N}$ input changed the microbial community. Perez et al. (2004) found that $\mathrm{N}_{\mathrm{SMB}}$ increased with increasing $\mathrm{TN}$ in the soil. The higher concentrations of $\mathrm{N}_{\mathrm{SMB}}$ and $\mathrm{C}_{\mathrm{SMB}}$ might contribute to the increase in TOC under sunn hemp, even without differences in $\mathrm{C}_{\mathrm{SMB}} / \mathrm{TOC}$ ratio (Table 7). Souza and Melo (2000) also observed an increase in $\mathrm{N}_{\text {SMB }}$ with sunn hemp under NT in the superficial soil depth, which can be explained by the presence of residues containing proteins, amino acids, nucleic acids, and other easily degradable materials (Mengel, 1996), which increase the concentration of potentially mineralizable N. Souza and Melo (2000) observed also concentrations of $\mathrm{N}_{\mathrm{SMB}}$ representing $4.15 \%$ of $\mathrm{TN}$ at $0-0.05 \mathrm{~m}$ soil depth, when sunn hemp was used as a cover crop, which were much higher than the values obtained under conventional tillage and/or without legumes. In the Typic Rhodudalf, the lack of effects of sunn hemp on $\mathrm{N}_{\mathrm{SMB}}$ and $\mathrm{N}_{\mathrm{SMB}} / \mathrm{TN}$ ratio was not expected, due to the higher TN from this legume and millet. However, the highest TOC and $\mathrm{TN}$ in the soil from sunn hemp were associated with relatively higher $\mathrm{C}_{\mathrm{SMB}}$. These results are in agreement with those reported by Gama-Rodrigues et al. (2005) showing the positive association of $\mathrm{C}_{\mathrm{SMB}}$ with TN in soils of different clay contents.

In this study, $\mathrm{N}_{\mathrm{SMB}}$ and the $\mathrm{N}_{\mathrm{SMB}} / \mathrm{TN}$ ratio from triticale were relatively higher (Table 7 ), even though there were no significant differences in the straw and $\mathrm{N}$ inputs from residues compared with sunflower (Table 4). This might have occurred due to the better soil cover with the triticale straw that prevented heating and drying, which are harmful to the microbial population or hinder root growth (Calonego and Rosolem, 2010). The lack of differences in $\mathrm{C}_{\mathrm{SMB}}$ between sunflower and triticale was not expected due to the relatively higher TOC with triticale at $0-0.10 \mathrm{~m}$ depth. It is possible that the concentration of SOM was not only associated with the microbial biomass, but also with the composition and activity of the microbial community (Joergensen and Emmerling, 2006). Residues with a higher proportion of water-soluble compounds are easily broken down by the majority of microorganisms in the soil and promote a higher microbial growth rate (Wolf and Wagner, 2005). However, if the organic supply is not constant, the scarcity of substrate may result in a decrease in the number and diversity of microorganisms (Diekow et al., 2005).

In both soil types, the crop rotations under NT had a qualitative and quantitative interaction with SOM, while $\mathrm{C}$ and $\mathrm{N}$ inputs played an important role in its increase. However, the effects of crop rotations on SOM quality/quantity was not related to the chemical composition of the species introduced in the rotation. The introduction of legumes in rotation systems as cover crops can 
be an appropriate option, because $\mathrm{N}$ input is very important in increasing TOC and its fractions.

\section{Conclusions}

The annual accumulation of dry matter and $\mathrm{N}$ in plant residues, especially of spring crops, influences the accumulation of soil TOC and its fractions, but species grown during the fall/winter have little effect on SOM concentration and quality in tropical soils in regions with dry winters. The introduction of Triticale and sunn hemp in the crop rotation improves the biological quality of the soil. Overall, the higher concentrations of TOC and its fractions as a result of the $\mathrm{N}$ input by crop residues indicate that under no-till SOM is affected also by the availability of $\mathrm{N}$, and not only by $\mathrm{C}$ deposition by cover crops. A higher $C$ input by cover crops increases labile $C$ in the SOM, decreasing its humification degree. However SOM humification degree is also decreased in systems with low $\mathrm{C}$ input (low dry matter yield) or systems were labile $C$ mineralization is faster (conventional tillage, or chiseling). Species like sunn hemp and triticale improve soil quality by increasing the $\mathrm{N}_{\mathrm{SMB}} / \mathrm{TN}$ without decreasing $\mathrm{TH}$. These results highlight the importance of cover crops and $\mathrm{N}$ inputs on SOM and soil conservation strategies aiming the sustainability of agricultural systems in the tropics.

\section{Acknowledgments}

This research was funded by FAPESP (The State of São Paulo Research Foundation) and CAPES (Coordination for the Improvement of Higher Education).

\section{References}

Balota, E.L., Colozzi-Filho, A., Andrade, D.S., Dick, R.P., 2003. Microbial biomass in soils under different tillage and crop rotation systems. Biol. Fert. Soils 38, 15-20.

Bayer, C., Dieckow, J., Amado, T.J.C., Eltz, F.L.F., Vieira, F.C.B., 2009. Cover crop effects increasing carbon storage in subtropical no-till sandy Acrisol. Commun. Soil Sci. Plant Anal. 40, 1499-1511.

Boddey, R.M., Jantalia, C.P., Conceição, P.C., Zanatta, J.A., Bayer, C., Mielnizuk, J., Dieckow, J., Santos, H.P., Denardin, J.E., Aita, C., Giacomini, S.J., Alves, B.J.R., Urquiaga, S., 2010. Carbon accumulation at depth in Ferralsols under zero till subtropical agriculture. Global Change Biol. 16, 784-795.

Boddey, R.M., Jantalia, C.P., Zotarelli, L., Aimée, O., Alves, B.J.R., Urquiaga, S., Amado, T.J.C., 2008. Nutrient mining or carbon sequestration? BFN inputs can make the difference. In: Dakora, F., Chimphango, S.B.M., Valentine, A.J., Elmerich, C., Newton, W.E. (Eds.), Biological Nitrogen Fixation: Towards Poverty Alleviation Through Sustainable Agriculture. Springer, Dordrecht, pp. 11-14.

Boddey, R.M., Victoria, R.L., 1986. Estimation of biological nitrogen fixation associated with Brachiaria and Paspalum grasses using ${ }^{15} \mathrm{~N}$ labelled organic matter and fertilizer. Plant Soil 90, 256-292.

Bolliger, A., Magid, J., Amado, T.J.C., Skora Neto, F., Ribeiro, M.F.S., Calegari, A., Ralisch, R., Neergaard, A., 2006. Taking stock of the Brazilian Zero Till Revolution. Adv. Agron. 91, 47-110.

Bronick, C.J., Lal, R., 2005. Soil structure and management: a review. Geoderma 124, $3-22$.

Calonego, J.C., Rosolem, C.A., 2008. Estabilidade de agregados do solo após manejo com rotações de culturas e escarificação. R. Bras. Ci. Solo 32, 1399-1407.

Calonego, J.C., Rosolem, C.A., 2010. Soybean root growth and yield in rotation with cover crops under chiseling and no-till. Eur. J. Agron 33, 242-249.

Cambardella, C.A., Elliot, E.T., 1992. Particulate soil organic-matter changes across a grassland cultivation sequence. Soil Sci. Soc. Am. J. 56, 777-783.

Castro, G.S.A., Crusciol, C.A.C., Calonego, J.C., Rosolem, C.A., 2015. Management impacts on soil organic matter of tropical soils. Vadose Zone J 14 (1) doi:http:// dx.doi.org/10.2136/vzj2014.07.0093.

Conceição, P.C., Dieckow, J., Bayer, C., 2013. Combined role of no-tillage and cropping systems in soil carbon stocks and stabilization. Soil Till. Res. 129, 40-47.

Diekow, J., Mielniczuk, J., Knicker, H., Bayer, C., Dick, D.P., Kögel-Knabner, I., 2005. Soil C and N stocks as affected by cropping systems and nitrogen fertilization in a Southern Brazil Acrisol managed under no-tillage for 17 years. Soil Till. Res. 81, 87-95.

Franzluebbers, A.J., 2002. Soil organic matter stratification ratio as an indicator of soil quality. Soil Till. Res. 66, 95-106.

Embrapa - Centro Nacional de Pesquisa de Solos, 1997. Manual de métodos de análises de solo, second ed. Embrapa-CNPS, Rio de Janeiro, Brazil.

Gama-Rodrigues, E.F., Barros, N.F., Gama-Rodrigues, A.C., Santos, G.A., 2005. Nitrogênio, carbono e atividade da biomassa microbiana do solo em plantações de eucalipto. R. Bras. Ci. Solo 29, 893-901.
Garcia, R.A., Li, Y., Rosolem, C.A., 2013. Soil organic matter and physical attributes affected by crop rotation under no-till. Soil Sci. Soc. Am. J. 77, 1724-1731.

Hargreaves, P.R., Brookes, P.C., Ross, G.J.S., Poulton, P.R., 2003. Evaluating soil microbial biomass carbon as an indicator of long-term environmental change. Soil Biol. Biochem. 35, 401-407.

Islam, K.R., Weil, R.R., 1998. Microwave irradiation of soil for routine measurement of microbial biomass carbon. Biol. Fert. Soils 27, 408-416.

Joergensen, R.G., Emmerling, C., 2006. Methods for evaluating human impact on soil microorganisms based on their activity, biomass, and diversity in agricultural soils. J. Plant Nutr. Soil Sci. 169, 295-309.

Kaiser, M., Ellerbrock, R.H., Gerke, H.H., 2008. Cation exchange capacity and composition of soluble soil organic matter fractions. Soil Sci. Soc. Am. J. 72, 1278-1285.

Kang, G.S., Beri, V., Sidhu, V.S., Rupela, O.P., 2005. A new index to assess soil quality and sustainability of wheat-based cropping systems. Biol. Fert. Soils 41, 389398.

Kappes, C., Arf, O., Andrade, J.A.C., 2013. Coberturas vegetais, manejo do solo, doses de nitrogênio e seus efeitos na nutrição mineral e nos atributos agronômicos do milho. R. Bras. Ci. Solo 37, 1322-1333.

Larson, W.E., Pierce, F.J., 1994. The dynamics of soil quality as a measure to sustainable management. In: Doran, J.W., Coleman, D.C., Bezdicek, D.F., Stewart, B.A. (Eds.), Defining Soil Quality for a Sustainable Environment. SSSA Special Publication No. 35, Madison, WI, USA, pp. 37-51.

Mendonça, E.S., Matos, E.S., 2005. Matéria orgânica do solo: Métodos de análises. 1. ed., Federal University of Viçosa, Viçosa, 107p.

Mengel, K., 1996. Turnover of organic nitrogen in soils and its availability to crops. Plant Soil 181, 83-93.

Milori, D.M.B.P., Galeti, H.V.A., Martin-Neto, L., Dieckow, J., González-Pérez, M., Bayer, C., Salton, J., 2006. Organic matter study of whole soil samples using laser-induced fluorescence spectroscopy. Soil Sci. Soc. Am. J 70, 57-63.

Mooshammer, M., Wanek, W., Hämmerle, I., Fuchslueger, L., Hofhansl, F., Knoltsch, A., Schnecker, J., Takriti, M., Watzka, M., Wild, B., Keiblinger, K.M., ZechmeisterBoltenstern, S., Richter, A., 2014. Adjustment of microbial nitrogen use efficiency to carbon:nitrogen imbalances regulates soil nitrogen cycling. Nat. Commun. 5 , 1-7. doi:http://dx.doi.org/10.1038/ncomms4694 (n.3694).

Nunes, R.S., Lopes, A.A.C., Souza, D.M.G., Mendes, I.C., 2011. Sistemas de manejo e os estoques de carbono e nitrogênio em Latossolo de cerrado com a sucessão sojamilho. R. Bras. Ci. Solo 35, 1407-1419.

Peoples, M.B., Baldock, J.A., 2001. Nitrogen dynamics of pastures: nitrogen fixation inputs, the impact of legumes on soil nitrogen fertility, and the contributions of fixed nitrogen to Australian farming systems. Aust. J. Exp. Agr. 41, 327-346.

Perez, K.S.S., Ramos, M.L.G., Mcmanus, C., 2004. Carbono da biomassa microbiana em solo cultivado com soja sob diferentes sistemas de manejo nos Cerrados. Pesq. agropec. bras. 39, 567-573.

Perin, A., Santos, R.H.S., Urquiaga, S.S., Cecon, P.R., Guerra, J.G.M., Freitas, G.B., 2006 Sunnhemp and millet as green manure for tropical maize production. Sci. Agric. 63, 453-459.

Puget, P., Drinkwater, L.E., 2001. Short-term dynamics of root- and shoot derived carbon from a leguminous green manure. Sci. Soc. Am. J 65, 771-779.

Raij, B., van, Andrade, J.C., Cantarella, H., Quaggio, J.A., 2001. Análise química para avaliação da fertilidade de solos tropicais. Instituto Agronômico, Campinas.

Santos, C.H., Romano, R.A., Nicolodelli, G., Carvalho, C.M., Villas-Boas, P.R., MartinNeto, L., Montes, C.R., Melfi, A.J., Milori, D.M.B.P., 2015. Performance evaluation of a portable laser-induced fluorescence spectroscopy system for the assessment of the humification degree of the soil organic matter. J. Braz. Chem. Soc. 26, 775-783.

Sas Institute, 2009. SAS 9.2. SAS Institute Inc, Cary, NC.

Schimel, J., Balser, T.C., Wallenstein, M., 2007. Microbial stress-response physiology and its implications for ecosystem function. Ecology 88, 1386-1394.

Schmidt, M.W., Torn, M.S., Abiven, S., Dittmar, T., Guggenberger, G., Janssens, I.A Kleber, M., Kogel-Knabner, I., Lehmann, J., Manning, D.A., Nannipieri, P., Rasse, D. P., Weiner, S., Trumbore, S.E., 2011. Persistence of soil organic matter as an ecosystem propoerty. Nature 478, 49-56.

D.J. Silva, A.C. Queiroz, (2002). Análise de alimentos (métodos químicos e biológicos), third.ed. UFV, Viçosa-MG.

Sisti, C.P.J., Santos, H.P., Kohhann, R., Alves, B.J.R., Urquiaga, S., Boddey, R.M., 2004 Change in carbon and nitrogen stocks in soil under 13 years of conventional or zero tillage in southern Brazil. Soil Till. Res. 76, 39-58.

Smagin, A., Sadovnikova, N., Nasrova, T., Kiryushova, A., Mashika, A., Eremina, A., 2004. The effect of organic matter on the water retention capacity of soils. Eurasian Soil Sci. 17, 267-275.

Soil Survey Staff, 2014. Keys to Soil Taxonomy, 12th ed. USDA-Natural Resources Conservation Service, Washington, DC.

Souza, W.J.O., Melo, W.J., 2000. Teores de nitrogênio no solo e nas fraç̃es da matéria orgânica sob diferentes sistemas de produção de milho. R. Bras. Ci. Solo 24, 885 896.

Sparling, G.P., 1992. Ratio of microbial biomass carbon to soil organic carbon as a sensitive indicator of changes in soil organic matter. Aust. J. Soil Res. 30, 195207.

Stevenson, F.J., 1994. Humus Chemistry: Genesis, Composition, Reactions, 2nd ed. Wiley, New York.

Stevenson, F.J., 1982. Organic forms of soil nitrogen. In: Stevenson, F.J. (Ed.), Nitrogen in Agricultural Soils. America Society of Agronomy, Madison, Wisconsin, pp. 67122512 pages.

Tivet, F., Sá, J.C.M., Lal, R., Borszorwskei, P.R., Briedis, C., Sántos, J.B., Sá, M.F.M., Hartman, D.C., Eurich, G., Farias, A., Bouzinac, S., Séguy, L., 2013. Soil organic 
carbon fraction losses upon continuous plow-based tillage and its restoration by diverse biomass-C inputs under no-till in sub-tropical and tropical regions of Brazil. Geoderma 209-210, 214-225.

Wattel-Koekkoek, E.J.W., Van Genuchten, P.P.L., Buurman, P., Van Lagen, B., 2001 Amount and composition of clay-associated soil organic matter in a range of kaolinitic and smectitic soils. Geoderma 99, 27-49.

Wolf, D.C., Wagner, G.H., 2005. Carbon transformations and soil organic matter formation, In: Sylvia, D.M., Fuhrman, J., Hartel, P.G., Zuberer, D.A. (Eds.),
Principles and applications of soil microbiology. 2nd ed. Prentice Hall, Upper Saddle River, NJ, pp. 285-332.

Wright, A.L., Dou,F, Hons, F.M., 2007. Crop species and tillage effects on carbon sequestration in subsurface soil. Soil Sci. 172, 124-131.

Zech, W., Senesi, N., Guggenberger, G., Kaiser, K., Lehmann, J., Miano, T.M., Miltner, A., Schroth, G., 1997. Factors controlling humification and mineralization of soil organic matter in the tropics. Geoderma 79, 117-161. 